\title{
Are the communal forest owners involved in the management of their lands? A qualitative analysis for the case of Galicia (Spain)
}

\author{
¿Los propietarios de bosques comunales están involucrados en la gestión de sus tierras? \\ Un análisis cualitativo para el caso de Galicia (España)
}

\author{
Manuel Francisco Marey-Pérez a*, Alexia Calvo-González a, Gloria Domínguez-Torres b \\ *Corresponding author: ${ }^{\text {a }}$ Universidad de Santiago de Compostela, Instituto Universitario de Estudios y Desarrollo de Galicia \\ (IDEGA), Departamento de Ingeniería Agroforestal, Campus Universitario, s/n, 27002, Lugo, España, \\ tel.: + 34 982823248, ext. 23248 / 23247, fax: +34 982285 926, manuel.marey@usc.es \\ b Centro Tecnológico Forestal de Cataluña (CTFC), Lérida, España.
}

\begin{abstract}
SUMMARY
Society's participation in decisions regarding land planning and management is essential to reach viable and long-lasting solutions in forest management. We analyzed the participation of communal land owners to better understand their attitudes towards the management of this property. Glaser and Strauss' Grounded Theory (1967) was used to build knowledge on the management of the property that starts in this study through the interpretation of data from personal interviews conducted in a participation process. We chose a sample of neighboring communities to conduct interviews according to the interest shown in the public participation process of a Forest Plan in a mountain area in the Autonomous Community of Galicia in northwest Spain. The communities were classified into i) very active, ii) active and iii) passive, according to their management level and geographical representation. We discovered the most active communities have more dynamic management due to their multifunctional perspective of communal forests. Regarding passive communities, their lack of interest in management is largely to recognizing a conflicted identity of the property due to physical and administrative problems.
\end{abstract}

Key words: forest planning, grounded theory, neighborhood, public participation.

\section{RESUMEN}

La participación de la sociedad en las decisiones relativas a la planificación y gestión de la tierra es esencial para alcanzar soluciones viables y duraderas en el manejo forestal. Se analizó la participación de los propietarios de las tierras comunales para comprender mejor sus actitudes hacia la gestión de esta propiedad. Se utilizó la Grounded Theory, de Glaser y Strauss, para construir el conocimiento sobre la gestión de la propiedad que se inicia en este estudio a través de la interpretación de los datos de entrevistas personales llevadas a cabo en un proceso de participación. Elegimos una muestra de comunidades vecinales para realizar entrevistas de acuerdo con el interés mostrado en el proceso de participación pública del Plan Forestal en una zona de montaña en la Comunidad Autónoma de Galicia en el noroeste de España. Las comunidades fueron clasificadas en i) muy activa, ii) activa y iii) pasiva, de acuerdo a su nivel de gestión y representación geográfica. Descubrimos que las comunidades más activas tienen una gestión más dinámica debido a su perspectiva multifuncional de los montes comunales. Y con respecto a las comunidades pasivas, su falta de interés en la gestión se debe principalmente al reconocimiento de una identidad conflictiva de la propiedad debido a problemas de origen físico y administrativo.

Palabras clave: planificación forestal, teoría fundamentada, comunidades vecinales, participación pública.

\section{INTRODUCTION}

Social changes in the last decades have marked a transition point in the concept of forest management. The changes in the structure and aim of forest property have not only influenced the maximization of forest exploitation (Pattanayak et al. 2002), but also the attitude and motivation of its owners (Karppinen 2005). Lehtinen (1994) deals with the new demands of society on forest land such as those related to the enjoyment of the natural environment, which are very different from the pre-existing ones linked to agriculture and stockbreeding, as stated by Gómez Váz- quez et al. (2009). According to Jönsson and Gustavsson (2002), it is important to consider strategic planning measures that provide new approaches to respond to these new social attitudes and motivations in forest management.

The need to understand the perspectives and interests of forest owners determines the use of information about the goal of the different stakeholders in the forestry sector. From 1980s onwards in Europe, studies have been increasingly focused on the behavior and motivations of forest owners (Bliss and Martin 1989, Butler et al. 2007), though in Spain, the first studies of forest owners date from the last decade (Marey-Pérez et al. 2006, Rodríguez-Vicente 
and Marey-Pérez 2008, 2009, 2010, Domínguez and Shannon 2009, Marey-Pérez et al. 2009).

Due to what has been exposed above, political systems have the power to ensure citizen participation in environmental decisions. According to Kouplevatskaya-Yunusova and Buttoud (2006) and Dhubháin et al. (2009), the mechanisms of public participation in decision making in the forest sector must be put into practice incorporating them into ground planning and as an instrument that may help to improve the forest sustainable management as indicated by Pan-European Sustainable Forest Management (PEFC) Criteria and Indicators (Stupak et al. 2010). Thus, the effort that those in charge of forest management must make should be translated into the elaboration of Forest Plans (Domínguez et al. 2005) where the need for valuable information for such development will be satisfied by participatory processes. The different approaches used for the study of this type of information have been predominantly hypothetical-deductive. The design of this study is constructivist and inductive, given the advantages derived from a qualitative methodology (Domínguez and Shannon 2009, Mutshewa 2010).

In this context, the aim of this paper is to improve the level of knowledge of the management that the collective forest owners realize upon having qualitatively evaluated their opinions in a process of public participation for the development of a forest plan of their grounds. The purpose is to be able to help in the making of strategic decisions of performance of these properties to improve their sustainable use in the future. We applied Grounded Theory (GT) to explore and analyze the opinions and attitudes of this group towards the management of their lands. GT was chosen as an empirical and qualitative method to study social life and is used for data collection and analyses (Glaser and Strauss 1967, Charmaz 2006). This methodology builds an increasingly more complex representation of the social phenomena studied and interpreted (Domínguez and Shannon 2009); having, thus, a constructivist character. Ideas arise from data interpretation without previous hypotheses (Creswell 1998), in contrast with hypothetic-deductive methods in which trial data are collected to test predetermined hypotheses (Domínguez and Shannon 2009).

\section{METHODS}

Study area. Galicia is characterized by possessing a highly important forestry area, which represents over $60 \%$ of its surface and $11 \%$ of Spanish forest surface. Galicia is made up of four provinces, nineteen forest districts, 315 councils and 3,793 parishes, with agricultural areas and forestry tradition and a high potential productivity (Marey-Pérez et al. 2006), which is the basis of the economy in many rural areas (Álvarez et al. 2006). Regarding the representativeness of rural and forest properties in Galicia, more than two thirds are privately owned, whereas $30 \%$ are communalcollectively owned; a characteristic property type in Galicia, known as “Montes Vecinales en Mano Común” (Bal- boa et al. 2006, Marey-Pérez et al. 2006, Gómez Vázquez et al. 2009). This land-tenancy scheme is a type of private collective property that belongs to groups of neighbors: "comuneros". They have several characteristics of rural society (Elands et al. 2004) since they are both owners and managers of economic and productive units, and residents of the areas where communal lands are located. The land is managed in a participative and associative manner. This type of property has a huge potential for forest exploitation since its average size is 230 ha, far bigger than the average individual privately-owned parcel (1.5 - 2 ha per owner) (Rodríguez-Vicente and Marey-Pérez 2008).

The process of public participation took place in the making of a Forest Plan in the District VII, A FonsagradaOs Ancares in the east of Lugo province (figure 1).

Material and methods. The process started with an informational phase about the right of participation of all those interested in the area. After all participants registered, different working groups were formed with representation depending on the degree of relationship with the forest (e.g., owners, hunters, business, Forest Administration) and geographical area. Later, a discussion process started regarding the opinion gathered from questionnaires and personal interviews related to PEFC Criteria and Indicators. Finally, the presentation of results and amendments was made public to later present a final document approved by all those involved (Marey-Pérez et al. 2009).

The research and analysis method was qualitative and inductive, inserted in a process of public participation. Using Grounded Theory (Glaser and Strauss 1967), data patterns that occurred at the beginning of the data-gathering process were observed. These data were later contrasted with additional data until a saturation point was reached (Strauss and Corbin 1990). Due to the nature of the methodology, according to Charmaz (2006), the sampling strategy is theoretically based, where the researcher deals with people, information and events. These enable the researcher to clarify and define the limits and the appropriateness of the theoretical concepts that are derived from data interpretation without deviating from the focus of analysis.

We chose a representative sample of private owners to be interviewed considering the following criteria: 1) interest and involvement in the participative process of writing a tactic Forest Plan for their forest properties; 2) being representative of the different levels of development and management of their land: very active, active and passive communities; and 3) according to geographical representativeness. We used a conversation guide which allowed us to deal with general topics: current land management, future perspectives of communal property and expectations regarding forest planning, among others. Interviews lasted for about an hour, in both Spanish and Galician. Field work, both interviews and observations, was carried out between March and June - 2009. Local circumstances of the study area have not undergone major changes from the indicated 


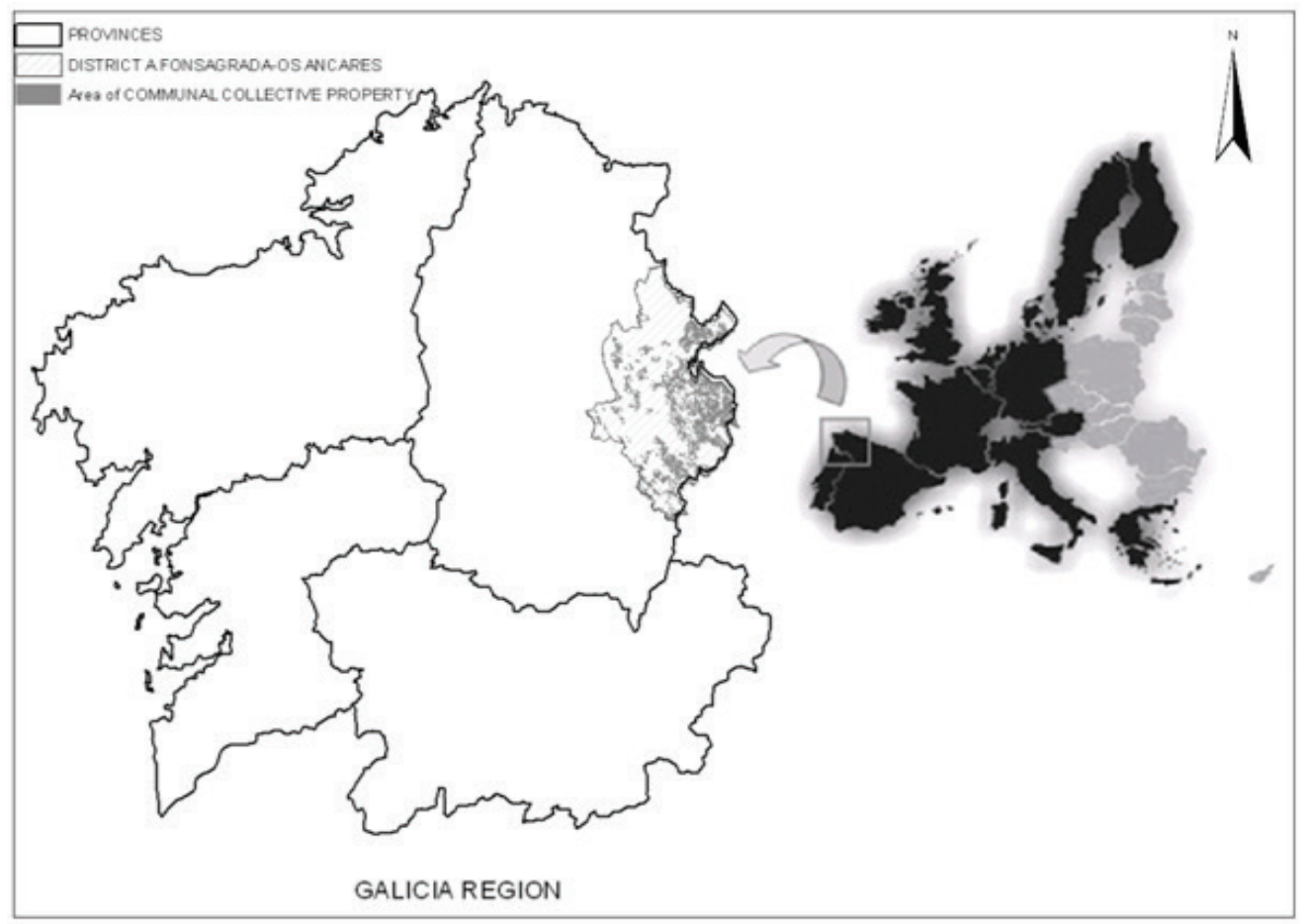

Figure 1. Location of collective private forests in the Fonsagrada-Os Ancares District, Galicia, Spain. Localización de los montes privados colectivos en el Distrito A Fonsagrada-Os Ancares, Galicia, España.

period. Interviews were sequentially recorded and transcribed (Hutchby and Wooffitt 1998) with the aid of Maxqda software (Ellis-Iversen et al. 2010), used to analyze texts in sociological research. Texts were transcribed as soon as possible after each interview, generating a document of more than 100 pages. As indicated by Strauss and Corbin (1990), the codification process is very important in qualitative data analyses. It consisted of assigning a label or code to each data segment with the aim of classifying or categorizing them for later analyses. The data-interpretation process allowed the addition of information with the aid of the writing of theoretical ideas (memos) about codes and their relationship, which arose from the constant comparison of all data (Trinidad et al. 2006). The conceptual integration of codes enabled the theoretical formulation of categories, which were a set of propositions that gave way to the final theory as indicated in the work of Creswell (1998). Finally, and according to the sequential methodological process (figure 2), we reviewed the bibliography about the topic at the end of the process to avoid preconceived ideas and to complete the theory obtained (Glaser 1998).

\section{RESULTS}

The process of public participation in the forest plan involved 453 participants from the different groups in the forestry sector. Figure 3 shows the degree of participation for each participating group.

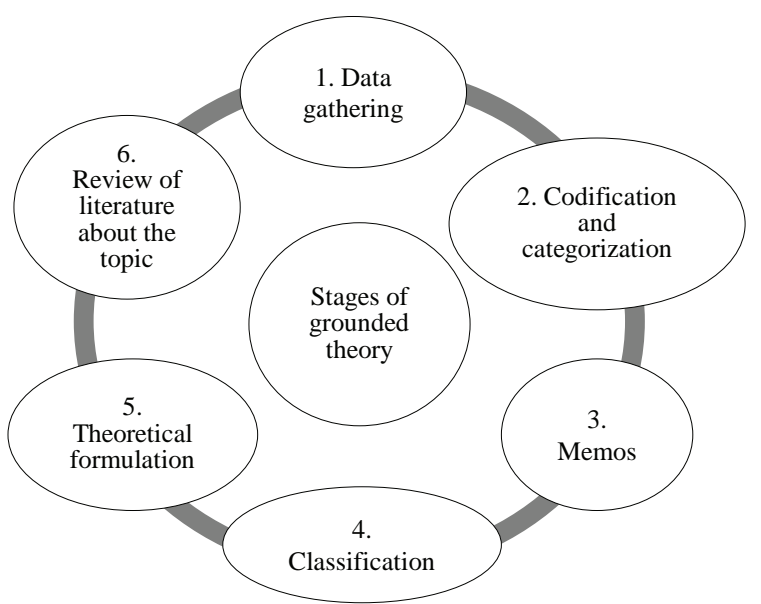

Figure 2. Phases of grounded theory methodology. Source: own elaboration.

Fases de la metodología de la Teoría Fundamentada. Fuente: elaboración propia.

Individual private owners and private collective owners constituted the majority of the participants. From the 68 participating groups, we chose eight representative private owners whose main characteristics are shown in table 1.

From the sample selected, we classified the communal land communities (figure 4) to be interviewed into: "very active communities" are those that have taken active part 


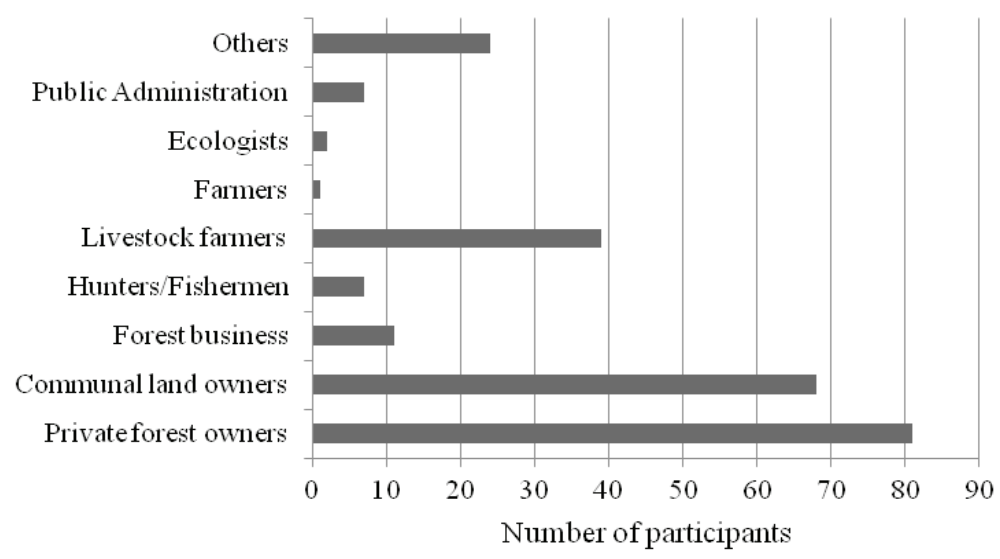

Figure 3. Degree of participation by group.

Grado de participación por grupos.

Table 1. Characteristics of the collective private owners interviewed. Características de los propietarios privados colectivos entrevistados.

\begin{tabular}{lccccc}
\hline Code & Gender & Age (year) & $\begin{array}{c}\text { Marital } \\
\text { status }\end{array}$ & Work activity & $\begin{array}{c}\text { Position on the } \\
\text { governing board }\end{array}$ \\
\hline E1/M9/C1 & M & $40-50$ & $\mathrm{~S}$ & Livestock farmer & No \\
E2/M3/C2 & M & $40-50$ & $\mathrm{~S}$ & Major & Yes: President \\
E3/M1/C3 & M & $60-70$ & $\mathrm{~S}$ & Pensioner & Yes: President \\
E4/M8/C4 & M & $20-30$ & S & Seller & Yes: Secretary \\
E5/M4/C5 & M & $50-60$ & Ma & Livestock farmer & Yes: President \\
E6/M3/C6 & F & $50-60$ & W & Social worker & Yes: President \\
E7/M6/C7 & F & $50-60$ & Ha & Housewife & Yes: President \\
E8/M7/C8 & F & $30-40$ & & Government & Yes: President \\
\hline
\end{tabular}

E1, E2, $E_{n}$ : number of interviews; M1, M2, $M_{n}$ council; C1, C2, $C_{n}$ : Community of communal land respondent; M: male, F: female; S: single, Ma: married, W: widow.

in the public participation process and that work effectively; "active communities" are those that have participated in the Forest Plan and that have acceptably managed their forest resources; "passive communities" are those that have not taken part in the public participation process and whose forest land organization and classification are deficient.

Conceptual categories derived from the Grounded Theory of communities with a higher degree of activity (very active and active) are:

- Forces that motivate the management of communal land communities.

- The acceptance of being responsible for the management of the communal collective property.

- Challenges for the management of the communal forests.

And the conceptual categories of the communities with a passive level of management are:
- Doubts about collective private property.

- Management restrictions in a demographically depressed area.

Forces that motivate the management of communal land communities. Three groups of answers can be distinguished within the common discourse about the neighborhood communities with an acceptable management level regarding their motivations for land management:

- Communal collective property as a big green bank. Expressions such as "support of primary income” or "an opportunity for rural population" justified such motivation. For some communities, this property represents an essential resource at economic, social and ecological level; hence, their exploitation is sustainable.

- Multiplicity of use of the communal collective property. Among the most common uses are pastures and reforestation for wood production (especially conife- 


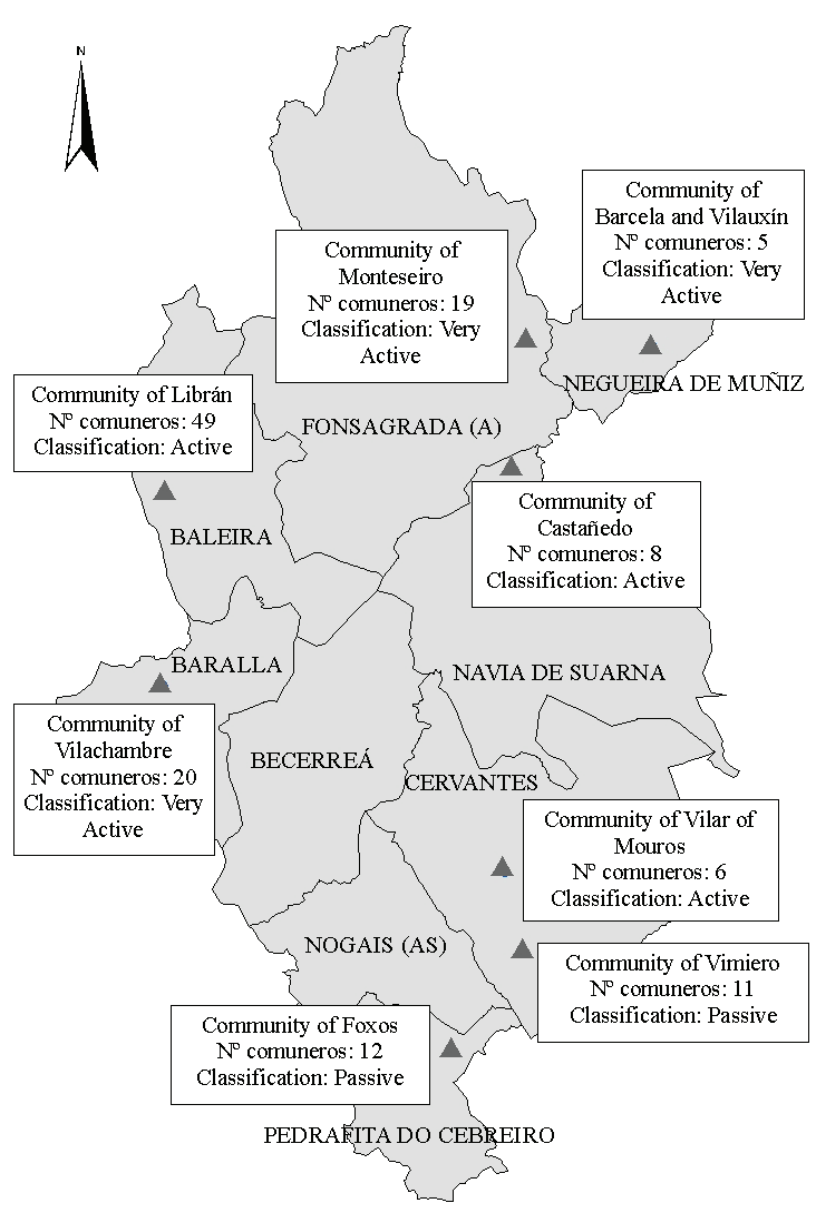

Figure 4. Location and classification of communal land communities interviewed.

Localización y clasificación de las comunidades vecinales entrevistadas.

rous). There are also initiatives based on exploitation models, such as installations, to produce renewable energies (wind and forest biomass) in their properties and the promotion of planting native hardwood species, making it compatible with stockbreeding and preservation of traditional uses.

- Acknowledgement of the subsidiary role of Regional Forest Public Administration. The positive valuation of public management recognized by most of the communal land communities is motivating. A well-known type of public action is the start of a Forest Plan, where the communities have manifested the need to participate to solve different problems that affect their property and highlight in this way the importance of their land in the area.

The acceptance of being responsible for the management of the communal collective property. Among the different reasons exposed, the coexistence of neighboring owners is shown in neighborhood associations and in management synergy that encourages consensus in decision-making regarding the community administration. In order to illustrate this attitude, some stated the characteristics of owner coexistence: "We try to get along the best we can...We almost always reach an agreement for the sake of the community, given the important task at hand" (E5/M4/C5). The majority of the most active communities assumed their responsibility due to the duality that characterizes their owners, who are both managers and recipients.

The takeover by a new generation in the communal land communities seems to be secured since some young people have undertaken some management tasks, helping the maintenance of this type of property and the future of forestry in these areas.

The presence of a leading manager that stimulates the activity of the community and that encourages the cooperation with the rest of the owners was considered as the hope for some communities.

The rights of the owners of these lands were discussed as well. One of the most remarkable differences between communal and private property is the possible moral rule that characterizes private owners. They represent the inheritance of a legacy from their ancestors that they must keep. In communal property, that legacy cannot be considered as such. However, there is the idea that the land has been exploited for a long time and it represents a right for those who live there.

Challenges for the management of the communal forests. Some of the difficulties that hinder the management intentions of the communities with higher activity have been classified in three groups:

- Critical characterization of the private collective owner profile. The lack of a collective initiative is an important issue. The minimum expenses and investments that characterize many owners are a challenge for the organization of the communal land communities. This stops their investment initiatives on the property, making them increasingly more dependent on public financial aid. Another factor is the lack of training, available to collective owners, on Forest Management: "The scarce information about forest management is a problem, but there are many people who support us" (E1/M9/C1). This lack of technical knowledge requires support staff from the Regional Administration or associations.

- Significant limitations in management. "Many owners cannot do their accounts" (E4/M8/C4); this statement about the difficulty of accounting procedures for collective private owners makes it necessary to hire specialized management societies, at an additional cost. There are also many complaints about the heavy taxation on this type of property, which is excessive when compared with that on private property.

- Problems inherent to the physical structure of the communal collective property. The conflictive identity of many of these properties was shown in expressions 
such as "fear of wildfires", "bad condition of infrastructures" or "problems with administrative limits". Social alarm caused by forest fires is closely related to questions such as intentionality, fuel accumulation due to forest abandonment, access difficulties owing to topographical reasons or lack of funds to carry out preventive activities. Some owners state the need for new infrastructure, but this must be carried out by the Forestry Administration as a result of the communities' lack of funding. The lack of definition in the administrative limits (demarcations) of some properties sometimes affects social relations among neighbors (lawsuits or revenges). Some communal land communities have tried to implement a conciliatory data system through a legal team, whereas others have trusted the planning of the Forest Plan.

Doubts about collective private property. We have collected some expressions such as "there is little to be done" (E7/M6/C7) showing that they are not aware of their responsibility and that in many cases the community is not constituted. Those communal land communities that act passively by not effectively managing their property following business criteria encourage management's immobility due to lack of confidence on the current possibilities of the communal forests.

Another factor is the lack of knowledge about the management system and the current legislation for these properties: "All those that leave the village do not have right over communal lands; that's why some prefer private property" (E2/M3/C2). This attitude has led to its transformation into individual property ownership.

Neighborhood independence, "each of us has a law", justifies the lack of cooperation, causing conflicts due to problems related to cattle in communal pastures or profit distribution.

Management restrictions in a demographically depressed area. Demographical problems (desertification and ageing population) that affect the area cause discouragement in the neighborhood communities and increase the reasons that limit property management and use.

The emigration of younger population looking for new working opportunities in urban areas is another aspect that respondents have emphasized. This situation endangers the future of the management of the passive communities.

Moreover, collective property is seen as secondary as it is becoming increasingly underused (only $30 \%$ of its surface is used). They have given up on finding new uses since they are only used for pasture and fast-growing plant species. There is also the problem with more other risks: wildfires, abiotic and biotic damage.

These communities show they mistrust based on the preconceived idea of their property taken away by the Administration. Resentment, in some statements, can be interpreted as a call for attention to these properties.

\section{DISCUSSION}

According to Kangas and Kangas (2005), no public participation method can be considered the best or can be applied to every situation. Grounded Theory had more advantages than more classical approaches due to the information necessary to make a Forest Plan. Diversity of opinions, ideas and proposals is a clear advantage contrasted with others. Moreover, the possibility of building theories, concepts, hypotheses and proposals straight from the data obtained in the field of study and not from previously obtained data makes Grounded Theory appropriate for the knowledge of a certain social phenomenon, as shown in the works of Charmaz (2006) and Trinidad et al. (2006). Consequently, taking the summary of the results of the studied social phenomenon as a sequence, the data are contextualized and discussed according to existing literature according to Glaser (1998).

Collective private forests are a source of wealth for the neighborhood communities presenting higher activity. Therefore, it must be preserved and managed in the best conditions, which is a moral rule shared by all the members of the social group. Bliss and Martin (1989) demonstrated that if a part of land has been managed by the same owners for a long time, it becomes a sign of identity for them. This concept of patrimonial heritage has been described in different works (Butler et al. 2007, RodríguezVicente and Marey-Pérez 2008).

As stated by González et al. (2007), the development of a communal property must take into account the multiple existing resources; hence, the potential of the forest or its enjoyment by future generations is not jeopardized. In agreement with Cubbage (2003), the forest is seen as a productive activity both for human well-being and economic profits. Therefore, the owners of these lands not only make decisions exclusively based on economic profits, but they also aim at maximizing the use instead of the profit according to the work of Pattanayak et al. (2002).

The new exploitation models that are intended to start in these communities have shown that harvesting activities are not seen as the only financial option for their land (Brunston and Reiter 1996). The rise of new sources of financial resources, such as renewable energies have caused important changes in land use and traditional management practices (Pardo and Gil 2005) that can help with the adaptation to the new socio-economical situation.

Forest planning must observe the different roles that it plays with a balance with the new demands of society (Lehtinen 1994). Thus, the actions in the communal forests must coincide with the interest of the community, but without forgetting the social interests of the owners. Consequently, the Forest Plan (Domínguez et al. 2005) as a tool must try to respond to the interest of the communal land communities, contributing in this way to improve their sustainable management (Dhubháin et al. 2009).

Following the principle of collective cooperation, the consolidation of the collective private property is linked 
with the recovery and normalized work of the neighborhood communities; based on community cooperation, which is not real in some cases nowadays (Marey-Pérez and Rodríguez-Vicente 2008). One of the causes of this disengagement from the community has a historical character. Authors such as Balboa et al. (2006), Marey-Pérez et al. (2006) and Marey-Pérez and Rodríguez-Vicente (2008) see its origin in the process of legal instability related to the tenancy of these properties throughout the 20th century, as they change owners successively, passing from private to public lands and later from public to collectively-owned, which is their current legal status (DOG 1989).

Taking into account that neighborhood communities are a living social cell that provides rural society with a high level of cohesion, those belonging to the most active ones work with an intrinsic motivation. They do not go after external rewards, but rather, they aim for the personal satisfaction of the fulfillment of their obligations as owners (Lindenberg 2001). This is the reason why research results coincide with Elands et al. (2004) statements, since the will to keep property in the future may be the key to guarantee the continuity of the forest sector in an area. Consequently, the future generations must be aware of the responsibility they have about property coinciding with Domínguez and Shannon (2009).

The support and recognition of the work of the neighborhood communities on the part of the Regional Forestry Administration, as indicated by Bliss and Martin (1990), occur for contributing the means technical assistance and the diffusion of the necessary information to support their communal management. Therefore, the starting point of the Forest Plan of the Galician Forest Administration responds to this initiative of social participation and serious commitment to put into practice politics adapted to the reality of the neighborhood communities (Jönsson and Gustavsson 2002, Kouplevatskaya-Yunusova and Buttoud 2006, Larsen and Nielsen 2007).

In accordance with the perspective of an irresponsible management of some communities that participate in the Forest Plan and due to the hypothetical-deductive focus of the methodology (Glaser and Strauss 1967), one of the external causes of these passive attitudes towards management, aside from the intrinsic factors of lack of capitalization and forest management training, is the decadence of the traditional agricultural model of the region (Riveiro et al. 2007). This has brought about a drastic decrease in the number of farms in this area. Linked to this decrease in the number of farms, there has been a decrease in the economic exploitation of the communal land resources (González et al. 2007). Another factor that explains immobilization in management is the decrease in the rural population that can work in these farms (Marey-Pérez et al. 2006, González et al. 2007). In the same way, the characteristics of the population have changed from urban to rural-urban (Barros 1999), where the economic forces are the secondary and tertiary sectors subtracting leader- ship to parishes, considered as areas of high agricultural and forestry tradition (Marey-Pérez et al. 2006). The primary sector is considered complementary by Nielsen et al. (2007), as it has been pointed out by these communities in the interviews.

As stated by Slovic (1987), when an owner believes that he or she has little control over the result of an event, the perceived risk and the disputes with their counterparts is higher. This coincides with the perception detected in the neighborhood communities that they are not responsible for the management of their property. The confrontation among owners due to differences in opinion regarding the management of these communities has caused deterioration in social relations, affecting thus community management (White et al. 2009). Unless there is a change in their perceptions, there will not be enough resources to solve their situation.

In order to help changing the trend in the management of the most passive owners, it is essential to consider political instruments that encourage their training in forest management to improve the management of their land, as they are not professionals of the sector and forest management is not usually their main income (Domínguez and Shannon 2009).

Administrative and physical problems in the management of these properties give the property a conflictive identity, according to Musselwhite and Herath (2007). The confrontation among owners due to lack of definition of the administrative limits of the communal forests has caused a series of lawsuits that increase conflicts in these lands. Moreover, their tax situation implies that their accountancy must be done similarly to that of mercantile societies (Rodríguez 2002). This causes difficulties in fulfilling their formal obligations without intermediaries, which causes conflicts between owners and Administration. Applications for public funding for the implementation of new exploitation models (mainly sources of energy) are interesting for some communities, but also a source of conflicts (Skutsch 2000) within the community (Brehm 2007), with institutions (Ibarra and Hirakuri 2007) or with concessionaires (De Jong et al. 2006). Due to all the reasons mentioned above, the political implications that must be activated must give technical-administrative support to the communities to simplify their administration work.

Within the category of conflicts of physical origin, wildfire recurrence is worth noting in these properties (Gómez-Vázquez et al. 2009), which increases the population's perception of insecurity. There are studies such as that by Badia and Mira (2007) that show land owners' perceptions of forest fires. For this territory, MareyPérez and Rodríguez-Vicente (2008) include the conflicts about ownership and communal management as a primary cause, coinciding with the results obtained in this study. It is urgent to set up preventive measures together with the encouragement of the promotion and advice of preventive forestry according to Tábara et al. (2003). 


\section{CONCLUSIONS}

There is not enough tradition or experience in the use of public participation in the processes of forest planning because their application has been linked to the territories with more economic resources and stronger forest tradition. But public participation in this sector would have a priority use in all territories because it is a key to achieving viable and lasting solutions factor. Therefore, in the coming years the contributions of citizens in decision-making in the different phases of the planning process will gradually become more important. Therefore, it is necessary to improve public participation in the forest sector.

The Grounded Theory methodology provides relevant information about human behavior in different social groups. In this case, through the analysis of interviews of the collective private owners, we have interpreted unpublished data regarding their motivations and strategies of land management.

The results show that there are two profiles of communal owners. A very active group within active communities that have positive attitudes and aptitudes towards traditional collective land management, who are also developing new management models adapted to the current and future reality. These owners think that Forest Plans are a tool that the Forest Administration must implement to increase its commitment with the rural areas, where they currently live and where they wish to live and work in the future. A second group is the passive communities, which show a total lack of interest for any type of management initiative. They think that little or nothing can be done to improve the current situation, which is the result of the rural and demographical crisis that they have suffered for the last thirty years.

The Forest Administration should be involved in the improvement of common land management. First, it should support the decisions of the very active and active communities. The participation of these communities in Forest Plans and the inclusion of their demands and opinions can contribute to this. It is more complicated to modify the behavior of passive communities. The lack of people with interest in managing their land is difficult to solve. Only two options are possible in the short and medium term: to show the results of active communities and copy these management models or transfer the partial management of the land to the Forest Administration.

\section{ACKNOWLEDGEMENTS}

The authors thank the collaboration of all those participants in the public participation process in the Forest Plan, especially to those of the Grounded Theory phase.

\section{REFERENCES}

Álvarez CJ, MF Marey-Pérez, JA Riveiro. 2006. Model of classification and characterization of farms for agricultural production planning. Application in the Northwest of Spain.
Proceedings of Agricultural Engineering for a Better World: 825-832.

Badia A, N Mira. 2007. Vulnerabilitat i percepció del risc d'incendi forestal en zones d'interfase urbana forestal. El cost real de viure a les árees d'interfase. Barcelona, Spain. In VI Trobada d'Estudiosos de Sant Llorenc del Munt i l’Obac. p. 187-191.

Balboa-López X, B Besteiro-Rodríguez, X Fernández-Leiceaga, L Fernández-Prieto, M Jordán-Rodríguez, E López-Iglesias, D Soto-Fernández, P Viso-Outeiriño. 2006. Os Montes Veciñais en man Común: O patrimonio silente. Natureza, economía, identidade e democracia na Galicia rural. Vigo, Spain. Edicións Xerais de Galicia. 520 p.

Barros C. 1999. De rural a rururbano: transformaciones territoriales y construcción de lugares al sudoeste del área metropolitana de Buenos Aires. Revista Electrónica de Geografía y Ciencias Sociales 45: 51-53.

Bliss J, JA Martin. 1989. Identifying NIPF management motivations with qualitative methods. Forest Science 35(2): 601-622.

Bliss J, A Martin. 1990. How tree farmers view management incentives. Journal of Forestry 88(8): 23-30.

Brehm J. 2007. Community Attachment: The Complexity and Consequence of the Natural Environment Facet. Human Ecology 35: 477-488.

Brunston M, DK Reiter. 1996. Effects of ecological information of judgments about scenic impacts of timber harvest. Journal of Environment Management 46: 31-41.

Butler BJ, M Tyrrell, G Feinberg, S Vanmanen, L Wiseman, S Wallinger. 2007. Understanding and reaching family forest owners: lessons from social marketing research. Journal of Forestry 105(7): 348-357.

Charmaz K. 2006. Constructing grounded theory. A practical guide through qualitative analysis. London, UK. Sage. 224 p.

Creswell R. 1998. Qualitative inquiry and research design: Choosing among 5 traditions. London, UK. Sage. 472 p.

Cubbage FW. 2003. The value of foresters. Forest Landowner 62(1): 16-19.

De Jong W, S Ruiz, M Becker. 2006. Conflicts and communal forest management in northern Bolivia. Forest Policy and Economics 8: 447-457.

Dhubháin A, MC Fléchard, R Moloney, D O’Connor. 2009. Stakeholders' perceptions of forestry in rural areas-Two cases studies in Ireland. Land Use Policy 26(3): 695-703.

DOG (Diario Oficial de Galicia, ES). 1989. Lei 13/1989 do 10 de octubre de Montes Veciñais en Man Común. p. 4924. (DOG $n^{\circ}$ 202).

Domínguez G, X Carbonell, E Plana, M Pecurul, I Rodríguez. 2005. Participación pública en el Plan General de Política Forestal en Cataluña. In IV Congreso Forestal Español. Zaragoza.

Domínguez G, M Shannon. 2009. A wish, a fear and a complaint: understanding the (dis) engagement of forest owners in forest management. European Journal Forest Research 130(2): 161-174.

Elands HM, T Oleary, H Boerwinkel, F Wiersum. 2004. Forests as a mirror of rural conditions; local views on the role of forests across Europe. Forest Policy and Economics 5: 469482.

Ellis-Iversen J, A Cook, E Watson, M Nielen, L Larkin, M Wooldridge, H Hogeveen. 2010. Perceptions, circumstances and motivators that influence implementation of zoonotic con- 
trol programs on cattle farms. Preventive Veterinary Medicine 94: 318-319.

Glaser BG, AL Strauss. 1967. The discovering of Grounded Theory. Chicago, EEUU. Aldine. 271 p.

Glaser BG. 1998. Doing Grounded Theory: Issues and Discussions. Mill Valley, CA, USA. The Sociology Press. 254 p.

Gómez-Vázquez I, P Álvarez-Álvarez, MF Marey-Pérez. 2009. Conflicts as enhancers or barriers to the management of privately owned common land: A method to analyze the role of conflicts on a regional basis. Forest Policy and Economics 11: 617-627.

González XP, MF Marey-Pérez, CJ Álvarez. 2007. Evaluation of productive rural land patterns with joint regard to the size, shape and dispersion of plots. Agricultural Systems 92: 52-62.

Hutchby I, R Wooffitt. 1998. Conversation analysis. Cambridge, UK. Polity Press. 256 p.

Ibarra E, SR Hirakuri. 2007. Institutional conflict and forest policy effectiveness: The case of the Costa Rican institutional reform. Forest Policy and Economics 9: 591-601.

Jönsson A, R Gustavsson. 2002. Management styles and knowledge cultures, past, present and future, related to multiple-use and urban woodlands. Urban Forestry and Urban Green 1: 39-47.

Kangas J, A Kangas. 2005. Multiple criteria decision support in forest management - the approach, methods applied and experiences gained. Forest Ecology and Management 207: 133-143.

Karppinen H. 2005. Forest owners' choice of reforestation method: an application of the theory of planned behaviour. Forest Policy and Economics 7: 393-409.

Kouplevatskaya-Yunusova I, G Buttoud. 2006. Assessment of an iterative process: The double spiral of re-designing participation Forest Policy and Economics 8: 529- 541.

Larsen JB, AB Nielsen. 2007. Nature-based forest managementwhere are we going? Elaborating forest development types in and with practice. Forest Ecology and Management 238: 107-117.

Lehtinen AA. 1994. The northern natures - a study of the forest question emerging within the timberline conflict in Finland. Geographical Society of Finland. Fennica 169(1): 57-169.

Lindenberg S. 2001. Intrinsic motivation in a new light. Kyklos 54(2): 317-342.

Marey-Pérez MF, V Rodríguez-Vicente, R Crecente-Maseda. 2006. Using GIS to measure changes in the temporal and spatial dynamics of forestland: experiences from northwest Spain. Forestry 79(4): 409-423.

Marey-Pérez MF, V Rodríguez-Vicente. 2008. Forest transition in Northern Spain: Local responses on large-scale programmes of field-afforestation. Land Use Policy 26: 139-156.

Marey-Pérez MF, L Rego-Vázquez, X Bruña-García, S Rodríguez-Pailos. 2009. El proceso de participación pública en la elaboración de un Plan de Ordenación de Recursos Forestales en la Comunidad Autónoma de Galicia. In V Congreso Forestal Español. Ávila, Spain.

Musselwhite G, G Herath. 2007. Chaos theory and assessment of forest stakeholder attitudes towards Australian forest poli- cy. Forest Policy and Economics 9: 947-964.

Mutshewa A. 2010. The use of information by environmental planners: A qualitative study using Grounded Theory methodology. Information Processing and Management 46: 212-232.

Nielsen AB, SB Olsen, T Lundhede. 2007. An economic valuation of the recreational benefits associated with naturebased forest management practices. Landscape and Urban Planning 80: 63-71.

Pardo F, L Gil. 2005. The impact of traditional land use on woodlands: a case study in the Spanish Central System. Journal of History and Geography 31: 390-408.

Pattanayak SK, BC Murray, RC Abt. 2002. How joint is joint forest production? An econometric analysis of timber supply conditional on endogenous amenity values. Forest Science 48(3): 479-491.

Riveiro JA, MF Marey-Pérez, JL Marco, CJ Álvarez. 2007. Procedure for the classification and characterization of farms for agricultural production planning: Application in the Northwest of Spain. Computers Electronics in Agriculture 61: 169-178.

Rodríguez D. 2002. Obrigas contables e fiscais das comunidades de montes veciñais en man común. O Monte 1: 18.

Rodríguez-Vicente V, MF Marey-Pérez. 2008. Assessing the role of the family unit in individual private forestry in northern Spain. Scandinavian Journal of Forest Research 23: 53-77.

Rodríguez-Vicente V, MF Marey-Pérez. 2009. Land-use and land-base patterns in non-industrial private forests: Factors affecting forest management in Northern Spain. Forest Policy and Economics 11(7): 475-490.

Rodríguez-Vicente V, MF Marey-Pérez. 2010. Analysis of individual private forestry in Northern Spain according to economic factors related to management. Journal of Forest Economics 16(4): 269-295.

Skutsch MM. 2000. Conflict management and participation in community Forestry. Agroforestry Systems 48: 189-206.

Slovic P. 1987. The perception of risk. Science 236(4799): 280285.

Strauss AL, J Corbin. 1990. Basics of qualitative research: Grounded Theory procedures and techniques. Newbury Park, CA, USA. Sage. 272 p.

Stupak I, B Lattimore, B Titus, T Smith. 2010. Criteria and indicators for sustainable forest fuel production and harvesting: A review of current standards for sustainable forest management. Biomass and Bionergy 35(8): 3287-3308.

Tábara D, D Saurí, R Cerdan. 2003. Forest fire risk management and public participation in changing socioenvironmental conditions: a case study in a mediterranean region. Risk Analysis 23(2): 249-260.

Trinidad A, V Carrero, RM Soriano. 2006. Teoría fundamentada “Grounded Theory” La construcción de la teoría a través del análisis interpretacional. Madrid, Spain. Centro de Investigaciones Sociológicas (CIS). 176 p.

White M, A Fischer, K Marshall, MJ Travis, J Webb, S Di Falco, M Redpath, R Vander Walf. 2009. Developing an integrated conceptual framework to understand biodiversity conflicts. Land Use Policy 26: 242-253. 
